\title{
SERTIFIKASI HALAL DI INDONESIA: \\ (Analisis Kuasa Simbolik dalam Kontestasi \\ Fatwa Majelis Ulama Indonesia)
}

\author{
Suad Fikriawan \\ Institut Agama Islam Sunan Giri Ponorogo \\ email: suad.fikriawan@gmail.com
}

\begin{abstract}
The MUI's symbolic power over halal certification in Indonesia constructed by the habitus of Muslim consumers who are becoming aware of halal lifestyles. beside it, the symbolic capital of the MUI and the political and social religious fields. When people expect the government to provide a solution to the issue of the distribution of consumer products containing material that is forbidden Islam, the government slowly respond to their aspirations, and even tend to do political engineering. then present the MUI with symbolic power instrument discourse the importance of established halal institutions in Indonesia. Through the old negotiations, finally there are some regulations that legitimize MUI and LPPOM as halal certification authority. in the Bourdieu study, halal certification LPPM MUI is a symbol system. The function of this symbol system is divided into three parts, the symbolic system as a structured structure, and Symbolic system as an instrument of domination. As a result, a structured group is created, a group that agrees with the authority of LPPOM MUI continues to campaign on the importance of halal certification of LPPOM MUI. and groups that do not agree to criticism, and sue the existence and authority of LPPOM MUI as the owner of halal certification authority in Indonesia.
\end{abstract}

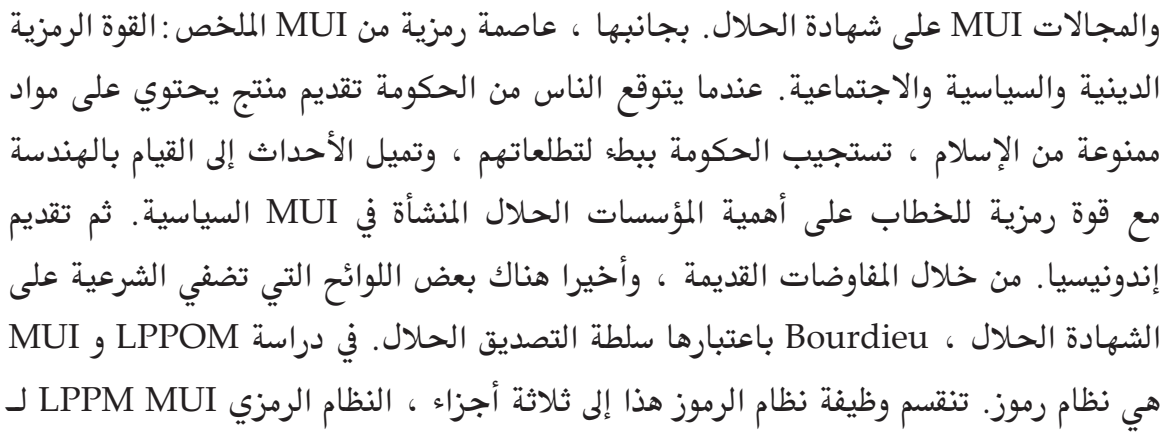


كهيكل منظم ، والنظام الرمزي كأداة للسيطرة. نتيجة لذلك ، يتم إنشاء مجموعة منظمة ،

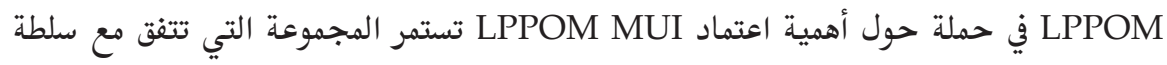

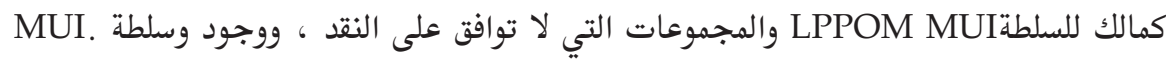
الحلال في شهادة إندونيسيا.

Abstrak: Kuasa simbolik MUI atas sertifikasi halal di Indonesia dibangun oleh habitus konsumen Muslim yang menjadi sadar akan gaya hidup halal. selain itu, modal simbolik MUI berikut arena politik dan social kala itu mendukung kuasa MUI. Ketika orang mengharapkan pemerintah memberi solusi untuk masalah distribusi produk konsumen yang mengandung zat yang dilarang Islam, pemerintah lamban merespon aspirasi mereka, dan bahkan cenderung melakukan rekayasa politik.kemudian menghadirkan MUI dengan wacana instrumen kekuasaan simbolik tentang pentingnya lembaga halal yang mapan di Indonesia. Melalui negosiasi yang lama, akhirnya terbitlah beberapa peraturan yang melegitimasi MUI dan LPPOM sebagai otoritas sertifikasi halal.dalam studi Bourdieu, sertifikasi halal LPPM MUI adalah sistem simbol. Fungsi sistem simbol ini dibagi menjadi tiga bagian, sistem simbolik sebagai pembentuk terstruktur, sistem simbol sebagai struktur yang dibentuk, dan sistem Simbolik sebagai instrumen dominasi.Akibatnya, kelompok terstruktur tercipta, mereka yang setuju dengan otoritas LPPOM MUI terus mengkampanyekan pentingnya sertifikasi halal LPPOM MUI. Disisi lain kelompok yang tidak setuju mengajukan kritik, dan menuntut keberadaan dan otoritas LPPOM MUI sebagai pemilik otoritas sertifikasi halal di Indonesia. Melalui kajian ini, nampak wacana Borudieu adalah tentang kontestasi yang menciptakan alat simbolis untuk mendominasi satu sama lain. Kontestasi ini terjadi antara MUI dan pemerintah, serta organisasi masyarakat, dan perusahaan, berikut masyarakat secara luas. Dan daripada lembaga sosial lainnya, MUI dapat memenangkan kontestasi dan mewujudkan kekuatan simbolisnya atas sertifikasi halal di Indonesia karena MUI memiliki habitus, modal, dan field yang lebih besar.

Keywords: kuasa simbolik, majelis ulama indonesia, sertifikasi halal 


\section{PENDAHULUAN}

Sejarah lahirnya Majelis Ulama Indonesia bermula dari sebuah kasus yang menghebohkan terjadi tahun 1988, Buletin Canopy edisi Januari tahun itu, yang diterbitkan oleh Senat Mahasiswa Fakultas Peternakan Universitas Brawijaya (UB) Malang memuat tulisan berupa laporan penelitian Ir. Tri Susanto, M.App.Sc yang menyatakan bahwa sejumlah produk makanan dan minuman terindikasi mengandung lemak babi. Tulisan tersebut telah menimbulkan kepanikan masyarakat baik dari kalangan konsumen muslim khususnya, maupun kalangan produsen produk pangan. Sejumlah produsen mengalami penurunan omset secara drastis. PT Sanmaru Food Manufacture, produsen Indomie mengaku penjualannya turun 20-30 persen dari omset 40 juta bungkus per-bulannya. Penjualan Kecap ABC melorot hingga 20 persen, dan Es Krim Campina yang sempat dikait-kaitkan dengan penelitian tersebut turun hingga 40 persen. Produsen Biskuit Siong Hoe, PT Tri Fabig terpaksa harus gencar mengklarifikasi melalui iklan bila produknya tidak haram. PT Food Specialties Indonesia (FSI) terpaksa juga mengeluarkan dana iklan Rp 340 juta, jumlah yang cukup besar ketika itu. ${ }^{1}$

Ketika terjadi kepanikan akibat menanggapi berita tersebut, yang diiringi upaya ekstra produsen untuk meningkatkan kepercayaan masyarakat terhadap produk, Pemerintah justru tidak segera mengambil kebijakan cepat dalam menyikapi peristiwa itu. Bahkan sikap yang dilakukan pemerintah cenderung berusaha menetralisir masalah dengan cara yang kurang proporsional. Seperti yang ditampilkan oleh Sekjen Departemen Agama (ketika itu) Tarmidzi Taher, dalam demonstrasinya meminum susu di sebuah pabrik di Pasuruan untuk diliput oleh media dengan maksud meredam gejolak di masyarakat.

Kesadaran masyarakat di Indonesia akan jaminan produk dari pemerintah adalah masalah yang penting sejak dekade itu. Umat Islam sebagai masyarakat mayoritas bisa terusik dengan beredarnya

${ }^{1}$ Aisjah Girindra. LPPOM MUI Pengukir Sejarah Sertifikasi Halal.(Jakarta: LPPOM MUI, 2005) 39-40 dan Thobieb al-Asyhar.Bahaya Makanan Haram. (Jakarta: Al Mawardi Prima, 2003) ,9-10. 
isu halal-haram, namun hiingga umat muslim menuntut kebijakan yang tegas dari pemerintah, hasilnya tetap nihil. Maka Majelis Ulama Indonesia (MUI) ${ }^{2}$ sebagai organisasi masyarakat mengambil langkah konkrit dengan melakukan sejumlah pertemuan membahas solusi yang meredam gejolak tersebut. Dari pertemuan-pertemuan yang diselenggarakan MUI itu maka diputuskan untuk mendirikan Lembaga Pengkajian Pangan, Obat-obatan, dan Kosmetika Majelis Ulama Indonesia yang kemudian disingkat LPPOM MUI. ${ }^{3}$

Terdapat satu wacana bahwa berdirinya LPPOM MUI tidak lepas dari kebijakan politik pemerintah orde baru. Proses negosiasi selama 10 tahun terakhir terkait kewenangan sertifikasi halal selalu berakhir pro-kontra. Pemerintah kurang impresif ketika berhadapan dengan aturan-aturan hukum Islam namun represif terhadap lembaga-lembaga yang berafiliasi pada keislaman. ${ }^{4}$

Maka, MUI yang hadir sebagai ahli nasehat dan fatwa agama, ketika melihat kehawatiran ini berkepanjangan, secara cepat meelakukan revitalisasi Lembaga Pengkajian dan Pengawasan Obat dan Makanan (LPPOM) dengan menyuarakan keinginan umat Islam untuk membangun sistem Jaminan Produk Halal yang sesuai dengan kondisi riil dilapangan dan menyelesaikan persoalan halal-haram produk pangan. Meskipun fatwa sertifikasi halal bersifat sukarela, namun keberadaannya dibutuhkan masyarakat.Gerakan ini selanjutnya memiliki daya tawar untuk melindungi umat Islam dari serbuan berbagai peredaran produk pangan yang mengandung bahan-bahan non-halal.

Harapan masyarakat kepada LPPOM MUI sebagai lembaga halal menjadi besar karena peran MUI sedemikian progresif dalam

\footnotetext{
${ }^{2}$ Upaya yang dilakukan oleh MUI tidak terlepas dari dorongan para intlektual muslim dan para ulama saat itu. MUI merupakan organisasi non pemerintah namun sifatnya sebagai organisasi forum lintas ormas.sehingga keberadaannya dipandang strategis dan mempunyai kedekatan khusus dengan pemerintah.

${ }^{3}$ HPA International, Sejarah LPPOM MUI dan Sertifikasi Halal di Indonesia, 06 Maret 2017.

${ }^{4}$ Moh. Mahfud MD, Membangun Politik Hukum,Menegakkan Kosntitusi (Jakarta: Rajawali Pers, Jakarta, 2010), 265.
} 
memanfaatkan habitus masyarakat melalui isu-isu halal. ${ }^{5}$ Sensitivitas masyarakat muslim dan kebiasaan yang terjadi di Indonesia dalam menghadapi isu-isu keagamaan khususnya persoalan pangan non-halal cenderung mengarahkan mereka pada perilaku yang tidak rasional, apalagi jika isu tersebut didukung oleh media yang berkepentingan untuk mengacaukan persepsi masyarakat Muslim. ${ }^{6}$ Maka MUI yang kiprahnya melindungi hak-hak keberagamaan bagi umat Islam, secara tepat memanfaatkan habitus inidenganmenginisiasi berdirinya LPPOM sebagai lembaga sertifikasi halal.

Ketika LPPOM MUI diresmikan, lalu peraturan perundangundangan dirumuskan, dan diteruskan dengan keluarnya keputusan pemerintah yang menunjuk MUI sebagai otoritas Sertifikasi Halal resmi, maka stigma masyarakat kemudian terfokus pada sertifikasi halal LPPOM MUI. Apabila Produsen ingin meyakinkan masyarakat tentang

${ }^{5}$ Secara sederhana habitus bisa didefinisikan sebagai kebiasaan yang berkelanjutan yang distrukturkan dalam kehidupan masyarakat sehingga ia tidak tampak lagi sebagai struktur, tetapi kewajaran yang seolah-olah tanpa kepentingan karena kehadirannya dianggap sebagai aturan yang menguntungkan seorang subjek dalam sebuah formasi sosial. Kebiasaan ini akan menjadi "doksa" (doxa) aturan-aturan sosial yang berubah menjadi "ortodoksa" (ortodoxa), yang diyakini kebenarannya karena akan mendatangkan ketertiban sosial. Namun, habitus tidak akan "menjadi" atau memperoleh pengakuan anggota masyarakat ketika ia tidak disosialisasikan melalui pewacanaan yang ajeg. Dalam Pierre Bourdieu, Language and Symbolic Power (Malden: Polity Press, 199), 165.

${ }^{6}$ Stetatemen Pierre Bourdieu tentang habitus ini dikuatkan oleh gagasan Foucault tentang wacana (discourse). Dalam pemahaman Foucauldian, wacana (discourse) yang merupakan sekelompok pernyataan yang menghasilkan bahasa untuk berbicara (sebuah cara untuk merepresentasikan pengetahuan) tentang topik tertentu pada momen historis tertentu: sebuah produksi pengetahuan melalui bahasa. Dari wacana itulah subjek-subjek dalam masyarakat menyandarkan pikiran dan tindakannya, apalagi ketika wacana tersebut disebarkan dalam formasi diskursif (discurssive formation) sehingga akan menjadi "rejim kebenaran" (regime of truth) yang diintrodusir terus-menerus dalam bentuk "pengetahuan" (knowledge). Media massa sebagai alat pewacana isu halal-haram produk, merupakan alat yang signifikan dalam mempengaruhi persepsi masyarakat. Dengan model pemberitaan yang berbedabeda, informasi yang sampai di masyarakat selalu menimbulkan kegelisahan dan kebingungan.Dan pihak produsen maupun pemerintah seringkali lambat untuk mengklarifikasi pemberitaan tersebut.Maka momentum ini dimanfaatkan MUI untuk meredam isu dan pemberitaan itu dengan tujuan agar kebingungan masyarakat tidak meluas dan berdampak buruk bagi perekonomian.Dikutip dari Michel Foucault.Power Knowledge (Brighton: Harvester, 2002): 50-52. 
produk halalnya maka produk yang dijual harus melalui proses sertifikasi halal MUI. Demikian sebaliknya bila masyarakat menginginkan produk halal, maka produk itu harus berlabel halal MUI. ${ }^{7}$

Kepercayaan masyarakat terhadap Sertifikasi Halal MUI dalam bahasa Gramsci adalah common sense yang tidak hanya netral dan bebas nilai, namun dapat dimanfaatkan untuk kepentingan ideologis tertentu. Dalam konteks Bourdieu, bahasa ternyata tak sekedar menjadi alat komunikasi yang mencakup sekumpulan kata-kata bermakna dalam sebuah proses pemahaman, tetapi ia juga menjadi instrumen kekerasan yang mengeksploitasi semesta simbolik dalam jejaring kekuasaan. Bahasa dipadati oleh berbagai kepentingan untuk memperebutkan legitimasi dan mendapatkan otoritas guna menamakan realitas. ${ }^{8}$

Bahasa sebagai media yang menguatkan habitus, dengan dukungan capital dan field yang relevan ini kemudian mengindikasikan kuasa simbolik nampak pada kewenangan LPPOM melalui kiprahnya selama 30 tahun. Selama itu belum ada satu lembaga yang menyamai peran dan fungsi LPPOM MUI.Pernah sekali pada tahun 2014 Badan Halal Nahdlatul Ulama (BHNU) melaksanakan sertifikasi halal atas produk-produk minuman yang bekerjasama dengan Sucofindo Jakarta.Meskipun biaya sertifikasi lebih murah dan pelayanan yang lebih cepat namun lembaga ini kemudian tidak mampu bertahan lebih lama. ${ }^{9}$

Di sisi lain, ada sebagian pihak yang menggugat otoritas LPPOM atas sertifikasi halal seperti yang dirilis oleh YLKI, bahwa LPPOM MUI tidak memiliki sistem pengawasan sertifikasi halal. Artinya, mekanisme kontrol post market tidak mampu dilakukan oleh MUI karena ketiadaan sumber daya. Kasus pemalsuan label halal, dan

${ }^{7}$ Fauzi Fashri, Pierre Bourdieu, Menyingkap Kuasa Simbol (Yogyakarta: Jalasutra, 2014), 188.

${ }^{8}$ Pierre Bourdieu"The Social Space and The Genesis of Groups" Transleted by Richard Nice Jurnal Theorie et methodes, Social Science Information (SAGE, London, Beverly Hills and New Delhi, 24, 2,1989) , 197.

${ }^{9}$ Mukafi, NU Online: Konsumen Puas Pelayanan Sertifikasi Halal NU, Senin 14 April 2014. 
munculnya isu kandungan haram produk yang tersertifikasi halal MUI menjadi salah satu indikasi lemahnya pengawasan tersebut. Jika dalam pasal 95 UU Pangan, ayat 1 menyebutkan pengawasan pangan halal dilakukan oleh Pemerintah Daerah dan Pemerintah Pusat, maka implementasinya boleh dikatakan tidak berlaku secara efektif. ${ }^{10}$

Maka, kajian ini menjadi menarik jika pertanyaan yang muncul adalah bagaimana selama ini peran LPPOM MUI dalam melakukan proses kuasa simboliknya dalam sertifikasi halal di Indonesia. Adapun analisis dalam kajian ini dilakukan dengan pendekatan Teori Kuasa Simbolik Pierre Bourdieu.

\section{KUASA SIMBOLIK MUI TERHADAP SERTIFIKASI HALAL}

Simbol dapat dijelaskan sebagai alat yang memiliki kekuatan untuk memperluas pengamatan, membangkitkan daya imajinasi, serta memperdalam pemahaman dan penghayatan. F. W Dillistone menunjukkan bahwa simbol mengandung tiga makna, pertama, sebuah kata, barang, obyek, tindakan, peristiwa, dan pola. Kedua, simbol mengandung makna yang mewakili, menggambarkan, mengisyaratkan, menyampaikan, dan lain sebagainya.Dan ketiga, simbol mengandung makna sesuatu yang lebih besar atau tertinggi atau terakhir; sebuah makna, realitas, atau suatu cita-cita.Simbol berfungsi sebagai penghubung aspek pertama dan aspek ketiga.Aspek pertama merupakan simbol dan aspek ketiga adalah referen dimana antara satu dengan yang lainnya saling bergantung. Ketika simbol hadir sebagai sebuah kata, gambar, obyek yang bersifat umum dan dapat dicerna oleh panca indra, saat itulah referen seolah menunggu untuk memberikan makna. ${ }^{11}$

Dengan begitu, sistem simbol memuat skema tanda tertentu yang merepresentasikan realitas tertentu.Sistem simbol memiliki kekuatan yang memberikan pemaknaan bagi realitas sosial. Lewat proses pen-

\footnotetext{
${ }^{10}$ Undang-undang Nomor 33 Tahun 2014 tentang Jaminan Produk Halal pasal 7.

${ }^{11}$ F.W. Dillistone, Daya Kekuatan Simbol; The Power of Symbols (Yogyakarta: Kanisius, 2002), 15-17. bandingkan dengan Fauzi Fashri, Pierre Bourdieu, Menyingkap Kuasa Simbol (Yogyakarta: Jalasutra, 2014), 117-118.
} 
citraan, sistem simbol memperoleh daya abstraknya untuk mengubah makna, menggiring cara pandang, hingga mempengaruhi praktik seseorang maupun kelompok. Kekuatan simbol ini mengandung energi magis yang membuat orang percaya, mengakui, serta tunduk atas kebenaran yang diciptakan oleh tata simbol.Kekuatan simbol mampu menggiring siapapun untuk mengakui, melestarikan, atau mengubah persepsi dan tingkah laku seseorang ketika bersentuhan dengan realitas.Daya magis simbol tidak hanya terletak pada kemampuan merepresentasikan kenyataan, tetapi kenyataan juga direpresentasikan lewat penggunaan logika simbol.Sehingga sistem simbol dalam perspektif ini memainkan peran yang saling berkaitan dan membentuk kuasa simbolik. ${ }^{12}$

Adapun fungsionalisasi sistem simbol dalam kuasa simbolik searas dengan konteks sertifikasi halal yang dijalankan oleh LPPOM MUI. Dalam teori Bourdieu, analisis terhadap peran kuasa simbolik oleh LPPOM MUI dapat dibaca melalui fungsi sistem simbol yang terbagi ke dalam tiga bagian, yaitu sistem simbol sebagai strukturstruktur yang membentuk, ${ }^{13}$ lalu sistem simbol sebagai strukturstruktur yang dibentuk, ${ }^{14}$ dan ketiga sistem simbol sebagai instrumen dominasi. ${ }^{15}$

${ }^{12}$ Pierre Bourdieu, “Social Space and Symbolic Power, Sociological Theory," Vol. 7, No. 1 (Spring, 1989), 14-25.

${ }^{13}$ Sistem simbolik ini berawal dari tradisi filosogis neo-Kantian, tradisi SapirWhorf atas bahasa, dan sosiologi pengetahuannya Durkheim.

${ }^{14}$ Selain melatih kerja kesadaran logika dalam sistem simbolik juga diatur lewat analisis struktural seperti yang dikembangkan oleh Saussure terhadap persoalan bahasa dan Levi-Strauss atas mitos.Sebagai Struktur-struktur yang dibentuk, sistem simbolik merupakan semesta tanda yang dihubungkan dengan makna struktur terdalam. Sistem makna terdalam ini berfungsi secara simultan terbagai instrumen komunikasi dan instrumen pengetahuan dan yang menjadi target akhir ialah integrasi sosial.

${ }^{15}$ Sistem simbolik berperan sebagai instrumen dominasi yang memberikan ciri khas tersendiri bagi instrumen teoritiknya.Semesta tanda yang diproduksi oleh sistem simbolis memberikan penyatuan bagi kelompok kelompok sosial dominan untuk menyebarluaskan kemapanan kode-kode pemahaman dan perilaku kepada kelompok-kelompok yang didominasi.Pierre Bourdieu, Language and Symbolic Power (Malden: Polity Press, 1991), 165. 


\section{SERTIFIKASI HALAL SEBAGAI BAGIAN DARI STRUKTUR YANG MEMBENTUK (STRUCTURING STRUCTURES)}

Pada awal munculnya isu produk yang mengandung bahan haram, masyarakat memiliki respon yang berbeda yang diwujudkan dalam bentuk reaksi terhadap pola konsumsi. Bagi masyarakat pada tingkat ekonomi dan pendapatan menengah, dengan pola konsumsi produk yang sebagian besar diproduksi sendiri, tidak terlalu peduli dengan isu tersebut, tetapi bagi masyarakat dengan tingkat ekonomi dan pendapatan tinggi sangat responsif dengan isu itu, salah satunya melalui gerakan boikot produk-produk pangan. Namun kemudian gerakan boikot itu cepat direspon oleh Majelis Ulama Indonesia untuk segera dilakukan langkah-langkah nyata dalam mengatasi isu tersebut.Hal ini berbeda dengan pemerintah yang cenderung menutupi atau bahkan merekayasa secara politik karena kepentingan tertentu.Maka persoalan haramnya produk-produk yang beredar di masyarakat pada tahun 1988 merupakan langkah pertama MUI menawarkan inisiatif untuk mendirikan LPPOM. Hal ini dilakukan karena situasi sosial masyarakat yang membutuhkan peran penting sebuah lembaga halal. Dan inisatif ini mendapatkan persetujuan dari pemerintah dan masyarakat muslim pada saat itu.

Pihak yang merasa keberatan atas inisiatif MUI adalah Dirjen Badan Pengawas Obat dan Makanan (BPOM).BPOM merasa lebih mempunyai kewenangan secara sah sebagai badan pemerintah. MUI sendiri menyatakan perlawanan dengan menyebutkan BPOM kurang baik kinerjanya dalam mengeluarkan sertifkasi halal. MUI khawatir kepada BPOM yang berisi birokrat dan tidak terlalu paham hukum halal dan haram akan lebih mempertimbangkan aspek kesehatan daripada kepentingan umat Muslim.Selain birokratnya bisa berganti-ganti, bisa saja dari agama lain. Klaim kewenangan untuk mengeluarkan sertifkasi halal juga terjadi pada Menteri Koordinasi dan Produksi (Menko Prodis) dan Menteri Perindustrian dan Perdagangan (Menperindag). ${ }^{16}$

${ }^{16}$ Dougall, John Mac. 1996. dalam Ketua MUI KH.Hasan Basri: “Kalau Umat Islam Tenteram,NegaraIniTenteram". 
Bagi MUI, UU Pangan No. 7 Tahun 1996 salah satu pasalnya secara implisit telah menyebutkan pangan yang diproduksi atau diimpor ke Indonesia harus mempunyai label halal atau sekurang-kurangnya menunjukkan produk tersebut halal. Dengan demikian, UU tersebut menjadi dasar pembelaan awal MUI terhadap kewenangannya. Sebelum adanya UU Pangan, Presiden Soeharto telah mengeluarkan Inpres No. 2 Tahun 1991 mengenai makanan halal kepada Menteri Koordinator Kesejahteraan Rakyat (Menkokesra). Melalui Instruksi Presiden tersebut, kemudian tugas itu dilimpahkan kepada tujuh menteri termasuk Departemen Agama dan Departemen Kesehatan, serta delapan gubernur.Dengan merujuk pada Inpres tersebut, makanan halal berada di bawah koordinasi Menkokesra.Dan Menkokesra menunjuk MUI untuk mengeluarkan sertifikasi halal. ${ }^{17}$

Memahami mekanisme kerja dari setiap rezim politik bukan hanya dilihat dan dianalisa dari praktik pengambilan kebijakan atau cara rezim mengatur kinerja pemerintahannya. Tapi dapat pula dilihat dari pola-pola simbolik yang digunakan oleh rezim politik, baik itu wacana yang diproduksi, tutur-bahasa yang digunakan, hingga pada proses pencitraan yang menggambarkan respon tiap rezim terhadap persoalan-persoalan politik yang terjadi.Menjadi lazim bagi setiap orde politik untuk menciptakan sistem simbol yang mencerminkan kekhasan kekuasaannya. Dalam konteks MUI, peran keagaamaan yang disuarakan melalui aksi dan legitimasi yang tereduksi dalam fatwa-fatwa serta nasehat keagamaan menjadi simbol yang tidak bisa dibantah oleh masyarakat maupun pemerintah. Pemilik simbol dapat mengejewantahkan dirinya seperti apa yang disimbolkan. Jika demikian, rezim politik bisa menjalankan praktik kekuasaannya atas nama simbol yang ia ciptakan sendiri. Ia memiliki wewenang untuk menjadikan simbol itu nyata dan mendapatkan pengakuan bahwa rezim politik memiliki mandat untuk bertindak sesuai dengan karakter yang disimbolkan.

${ }^{17}$ Abdurrahman Konoras, Jaminan Produk Halal di Indonesia, Perspektif Hukum Perlindungan Konsumen (Jakarta: Rajawali Press, 2017), 42. 


\section{SERTIFIKASI HALAL SEBAGAI BAGIAN DARI STRUKTUR YANG DIBENTUK (STRUCTURED STRUCTURES)}

Sistem simbolik juga diatur lewat analisis struktural seperti yang dikembangkan oleh Saussure terhadap persoalan bahasa dan LeviStrauss atas mitos.Lévi-Strauss lebih banyak mengkaji makna dalam yang menjadi penggerak dari lahirnya mitos dalam wujud dongeng maupun legenda di mana makna dalam itulah yang menjadi referensi bagi masyarakat partikular untuk menjalani hidup. ${ }^{18}$ Namun berbeda dengan Strauss, Barthes mendeskripsikan mitos sebagai praktik penandaan populer dalam masyarakat yang bertujuan untuk menyampaikan pesan ideologis secara natural sehingga melakukan depolitisasi terhadap kepentingan kuasa yang ada di baliknya. Deskripsi ini dilatarbelakangi oleh sebuah argumentasi bahwa simbol bisa menggunakan sebuah gerakan eks-nominasi untuk menyebarkan kepentingannya tanpa memberinya label karena mereka bisa masuk ke dalam ranah budaya yang selalu dianggap netral, nir-politik, sehingga pengaruhnya bukan lagi dianggap sebagai kepentingan kuasa, tetapi sebuah kemenangan bersama atas nama kemanusiaan itu sendiri. ${ }^{19}$ Sesuai dengan penjelasan itu, Bourdieu mendukung Barthes dengan memberikan istilah integrasi sosial. ${ }^{20}$

Pada saat pemerintah merumuskan regulasi tentang kewenangan sertifikasi halal ${ }^{21}$, beberapa peraturan yang telah disusun menyatakan bahwa MUI adalah lembaga yang relevan dalam melaksanakan sertifikasi

${ }^{18}$ Lévi-Strauss, Claude. Antropologi Struktural (terj) Ninik RS. (Yogyakarta: Kreasi Wacana,2005)

${ }^{19}$ Roland Barthes, Mytologies(The Noonday Press: Farrar, Straus \& Giroux, 1972)

${ }^{20}$ Pierre Bourdieu, Language and Symbolic Power (Malden; Polity Press, 1991), 166.

${ }^{21}$ Beberapa regulasi tersebut diantaranya UU No. 7 tahun 1996 tentang pangan yang disahkan tanggal 4November 1996, kemudian UU No 8 tahun 1999 tentang Perlindungan Konsumen disahkantanggal 20 April 1999, PP No. 69 tahun 1999 tentang Label dan Iklan Pangan ditetapkantanggal 21 Juli 1999, Keputusan menteri Agama No. 518 tahun 2001 tentang PedomanTatacara Pemeriksaan dan Penetapan Produk Halal ditetapkantanggal 30 November 2001, Keputusan menteri Agama No. 519 tahun 2001 tentang LembagaPelaksana Pemeriksaan Pangan Halal ditetapkan tanggal 30 November 2001, UU No. 18 tahun 2009 tentang Peternakan dan Kesehatan Hewandisahkan tanggal 4 Juni 2009. 
halal. ada pula peraturan lainnya yang secara eksplisit tidak menyebutkan lembaga tersebut namun mendukung program sertifikasi halal, dan ada pula peraturan yang menyatakan bahwa tahap pengawasan, pemeriksaan, pengujian, standarisasi, sertifikasi, dan registrasi dalam rangka menjamin produk hewan yang aman, sehat, utuh dan halal, menjadi kewenangan Pemerintah dan Pemerintah Daerah. ${ }^{22}$

Diketahui, dalam pernyataan peraturan-peraturan tersebut muncul adanya tumpang tindih kewenangan lembaga. Misalnya pasca diterbitkannya Peraturan Pemerintah No.69/1999, pada saat itu Kementerian Agama telah membuat konsep pedoman dan tata cara pemeriksaan pangan halal No. 518 tahun 2001. Konsep ini bukan hanya membahas persyaratan bahan, proses atau produknya, akan tetapi organisasi yang berhak mengeluarkan sertifkat halal. Hal ini sempat menimbulkan polemik, protes dan kontroversi.Sebelum konsep ini diputuskan maka harus ada masukan ke Kementerian Agama agar mau mengubahnya.Dalam konsep tersebut disebutkan bahwa lembaga yang mempunyai wewenang untuk mengeluarkan sertifikat halal di Indonesia adalah Komite Halal Indonesia (KHI). KHI terdiri atas unsur-unsur Kementerian Agama, Badan Pengawasan Obat dan Makanan (Badan POM), Kementerian Perindustrian dan Perdagangan, Kementerian Pertanian dan MUI. ${ }^{23}$

Permasalahannya, jika sertifikasi halal menjadimonopoli KHI yang notabene adalah unsur pemerintah yang bertugas membuat peraturan dan mengawasinya, maka pembuat peraturan dan pengawas memerankan fungsi ganda dalam sertifikasi, dan ini dikhawatirkan dapat menimbulkan hal-hal yang tidak diinginkan, misalnya BPOM bertugas menerbitkan sertifikasi da labelisasi halal, kemudian BPOM sendiri juga sebagai pengawas sertifikasi halal, maka sistem pengawasan menjadi subyektif dan hanya akan berkutat pada satu

\footnotetext{
${ }^{22}$ Mutimmatul Faidah. "Sertifikasi Halal di Indonesia dari Civil Society menuju Relasi Kuasa antara Negara dan Agama," Jurnal Islamica, Volume 11, Nomor 2, Maret 2017,465.

${ }^{23}$ Paisol Burlin, "Reformulasi Yuridis Pengaturan Produk Pangan Halal bagi Konsumen Muslim di Indonesia," JurnalAhkam: Vol. XIV, No. 1, Januari 2014, 44.
} 
atap saja. Maka kemudian Kementerian Agama menunjuk MUI dan BPOM sebagai lembaga pelaksana sertifikasi dan pengawasan produk halal, berdasarkan peraturan lainnya yang relevan dalam konteks MUI sebagai lembaga pelaksana sertifikasi halal.

Keputusan Kementerian Agama tersebut dikuatkan oleh Keputusan Menteri Kesehatan Republik Indonesia Nomor 924/Menkes/SK/ VIII/1996 tentang Perubahan atas Keputusan Menteri Kesehatan (Kepmenkes) Republik Indonesia Nomor 82/Menkes/SK/I/1996 tentang Pencantuman Tulisan "Halal" pada Label Makanan. Kepmenkes ini memuat perubahan penting atas Kepmenkes sebelumnya.Perubahan ini merupakan konsekuensi adanya Surat Keputusan Bersama tiga lembaga yaitu Kementerian Agama, Kementerian Kesehatan dan MUI. Pada prakteknya, jika ada suatu perusahaan ingin mencantumkan label halal (sekarang permohonannya ke badan POM), maka akan dilakukan pemeriksaan (auditing) ke perusahaan tersebut (setelah melengkapi persyaratan yang diminta)oleh tim gabungan dari badan POM, LPPOM-MUI dan Kementerian Agama. Untuk perusahaan lain yang tidak memerlukan label halal tetapi memerlukan sertifikat halal maka pengajuan sertifikat halal hanya kepada MUI. Misalnya produsen penghasil ingredient seperti industri flavor. ${ }^{24}$

Pasca keputusan peraturan yang menyepakati bahwa MUI dan BPOM adalah lembaga yang berwenang dalam melaksanakan sertifikasi halal dan labelisasi halal di Indonesia, maka jika ada lembaga lain yang mempelopori pendirian lembaga pemeriksa halal, kemungkinan bisa dilakukan karena tidak melanggar UU Perlindungan Konsumen (UUPK) maupun UU Pangan, maupun PP No.69/1999, dan tidak ada ketentuan tegas yang mengharuskan pemeriksaan halal dilakukan oleh LPPOM-MUI saja. Namun tentu saja lembaga pemeriksa ini harus diakreditasi oleh Komite Akreditasi Nasional.Dan mengingat masalah halal adalah masalah yang berkaitan erat dengan keagamaan secara langsung, maka keterlibatan ulama atau ahli fkih sangat diperlukan. Namun Organisasi Masyarakat maupun perusahaan yang mencoba

${ }^{24}$ Ibid., 47. 
mendirikan lembaga halal untuk ikut andil dalam pelaksanaan sertifikasi halal selalu terhambat oleh ketatnya regulasi maupun tidak adanya dukungan oleh sebagian masyarakat secara sosio-politis. ${ }^{25}$

Penolakan ini dalam diskursus Pierre Bourdieu diakibatkan oleh konstruksi budaya organisasi yang dikendalikan oleh kuasa simbolik. Disposisi masyarakat tentang sertifikasi halal LPPOM MUI sudah cukup kuat dan mapan yang kemudian melahirkan budaya yang dipraktikkan berdasarkan kesepakatan-kesepakatan.Kesepakatan ini adalah bentuk negosiasi dalam istilah Strauss.Untuk menyatakan bahwa budaya organisasi adalah tatanan yang dinegosiasikan tidak berarti kesetaraan dalam negosiasi.Sebaliknya, beberapa juru runding tertentu memiliki kekuatan yang tidak proporsional selama pesanan yang dinegosiasikan.Meskipun ada contoh paksaan yang jelas, lebih sering kekuatan ini tidak kentara, "kekuatan tak terlihat" disarikan dari hubungan antara manusia, bukan merupakan manifestasi dari peraturan dan wewenang formal. ${ }^{26}$

Dalam konteks hukum, Satjipto Rahardjo menguatkan bahwa salah satu proses pembentukan hukum (legislasi) adalah terpenuhinya tahap sosio politik. Dimana situasi sosial dan politik yang ikut terlibat dalam dialog pembentukan hukum sangat menentukan hasil keputusan hukum tersebut. ${ }^{27}$ Selaras dengan penjelasan Satjipto Rahardjo, Chambliss dan Seidman menyebutkan bahwa pada masyarakat dengan model konflik sekarang ini, ada beberapa kemungkinan yang dapat terjadi dalam pembentukan hukum, yaitu: (1) Pembentukan hukum akan dilihat sebagai suatu proses adu kekuatan, dimana negara merupakan senjata di tangan lapisan yang berkuasa. (2) Sekalipun terdapat pertentangan nilai-nilai di dalam masyarakat, namun negara tetap berdiri sebagaibadan yang tidak memihak (valueneutral), di mana nilai-nilai dan kepentingan-kepentingan yang bertentangan dapat

${ }^{25}$ Ibid., 49.

${ }^{26}$ Tim Hallet, "Symbolic Power and Organization Culture, Sociological Theory,"Vol. 21, No. 2 (Jun., 2003), 135.

${ }^{27}$ Satjipto Rahardjo, Membedah Hukum Progresif (Jakarta: Kompas, 2006) 177-178. 
diselesaikan tanpa mengganggu kehidupan masyarakat. ${ }^{28}$ Hal ini menunjukkan bahwa pembentukan peraturan perundang-undangan sebagai hasil dari proses kebijakan harus didasarkan pada keinginan orang banyak atau masyarakat sebagai pemangku kepentingan (stakeholders) dan tentu saja membutuhkan partisipasi masyarakat secara langsung maupun tidak langsung dalamsetiap prosesnya. ${ }^{29}$

Dalam kajian Pierre Bourdieu, konstruksi peraturan yang dilakukan pemerintah, merupakan konstruksi atas makna-makna dalam sistem simbol yang dikomunikasikan hingga membentuk suatu pengetahuan. ${ }^{30}$ Substansi diskursus ini semata hanya untuk membangun kesepakatan sosial (integrasi) atas siapa yang layak untuk memegang orotiras halal. Dengan obyek utama produsen dan konsumen muslim yang sadar halal. Dengan dua motif utama yang selalu disuarakan LPPOM MUI bahwa pentingnya sertifikasi halal dapat mewujudkan perlindungan konsumen muslim terhadap hak-haknya berupa keamana dalam berkonsumsi, serta meningkatkan kepercayaan masyarakat apabila produk yang dipasarkan produsen berlabel halal, maka langkah Sertifikasi halal LPPOM MUI menjadi diminati oleh produsen dan masyarakat. Apalagi Menghadapi globalisasi ekonomi, sertifikasi dan labelisasi halal makin diperlukan untuk menangkis saingan produk dari luar.Dengan sertifikasi halal maka produsen bisa merambah pasar yang lebih luas. Produsen juga tidak kesulitan lagi untuk meyakinkan konsumen terkait kehalalan produknya, dan produsen akan terjaga kredibilitasnya dihadapan konsumen muslim. Maka Sertifikasi halal sebagai amanat Undang-Undang Nomor. 18 Tahun 2012 tentang Pangan dan Undang-Undang Nomor 8 Tahun

${ }^{28}$ Ibid.

${ }^{29}$ KN. Sofyan Hasan, "Formulasi Hukum dan Pentingnya JaminanKepastian Hukum Produk Pangan Halaldalam Hukum Nasional," NURANI, Vol. 15, No. 2, Desember 2015, 67.

${ }^{30}$ Pierre Bourdieu, “Social Space and Symbolic Power, Sociological Theory", 165. 
1999 tentang Perlindungan Konsumen, harus dijalankan oleh yang berwenang yaitu LPPOM MUI. ${ }^{31}$

\section{SERTIFIKASI HALAL SEBAGAI INSTRUMEN DOMINASI (IN- STRUMENT OF DOMINATION)}

Pergeseran persepsi masyarakat yang banyak dipengaruhi aturan undangundang yang menegaskan pentingnya sertifikasi halal dan lembaga halal LPPOM MUI, membuat konsumen semakin mengerti bahwa produk yang berlabel halal adalah produk berkualitas dan tidak mengandung bahan yang diharamkan oleh Islam.Atas dorongan konsumen yang semakin mengerti tentang pentingnya produk bersertifikat halal, maka jumlah produk berlabel halal dari tahun ke tahun bertambah secara signifikan. Keterangan jumlah produk yang tersertifikasi dengan jumlah produk yang belum tersertifikasi sampai tahun 2017 berdasarkan laporan statistik LPPOM MUI dapat dilihat sebagaimana diagram berikut: ${ }^{32}$

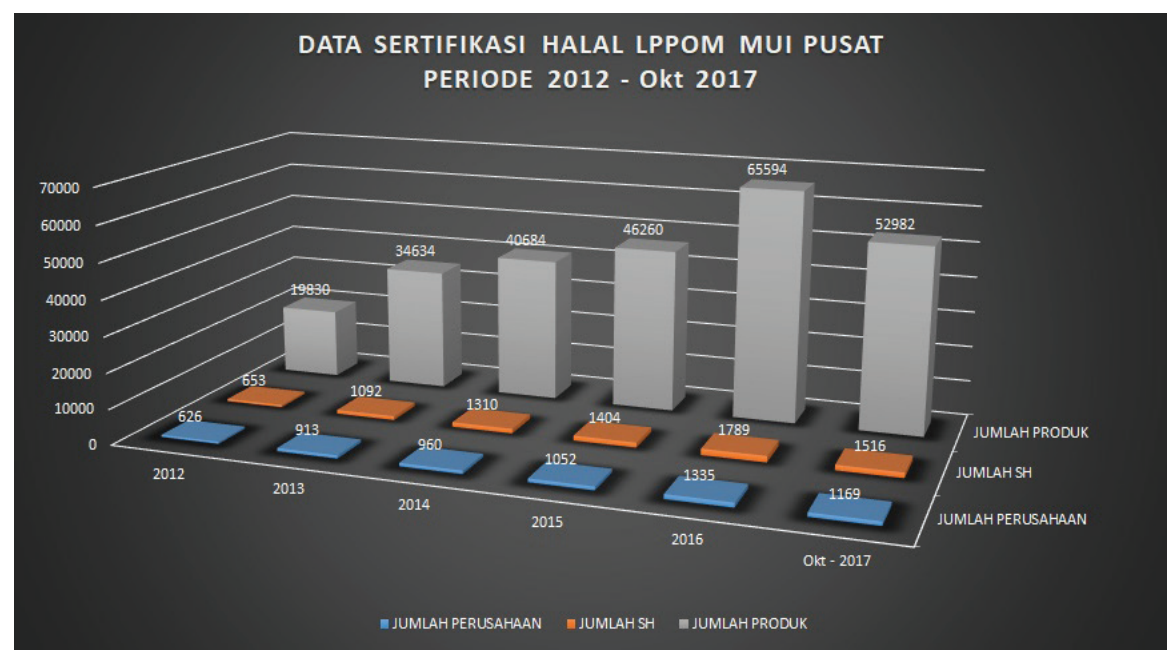

Gambar 1.

Data Sertifikasi Produk Halal LPPOM MUI Pusat

Periode 2012 - Oktober 2017

${ }^{31}$ KN. Sofyan Hasan, “Formulasi Hukum dan Pentingnya JaminanKepastian Hukum Produk Pangan Halaldalam Hukum Nasional", 55.

${ }^{32}$ Statsitik Sertifikasi Halal Indonesia, data diupdate per tanggal 11 Oktober 2017. 
Berdasarkan diagram diatas dapat dijelaskan bahwa mulai tahun 2012 sampai Bulan Oktober 2017 Jumlah perusahaan yang telah mengajukan sertifikasi halal kepada LPPOM MUI Pusat sebanyak 6.055 perusahaan dengan jumlah produk sebanyak 259.984 produk. Sedangkan data Sertifikasi halal di tingkat Propinsi dapat dilihat pada diagram berikut: ${ }^{33}$

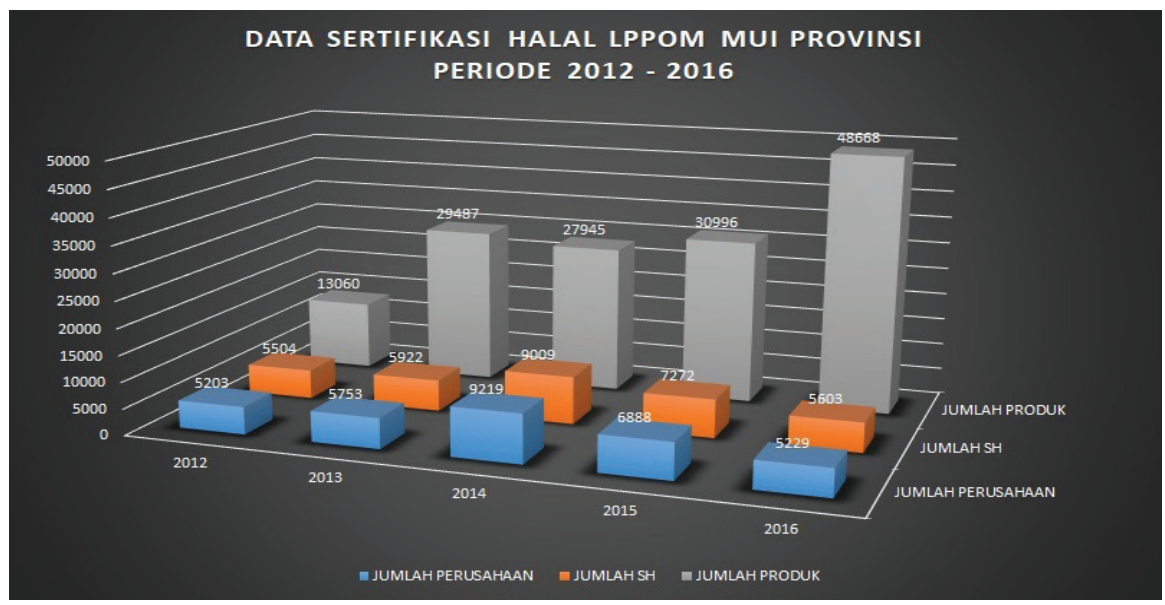

Gambar 2.

Data Sertifikasi Halal LPPOM MUI Provinsi Periode 2012-2016

Dari diagram diatas dapat diketahui bahwa sejak tahun 2012 sampai tahun 2016 jumlah perusahaan yang mengajukan sertifikasi halal di LPPOM Propinsi sebanyak 32.292 perusahaan, sedangkan jumlah produk keseluruhan sebanyak 150.156 produk. $^{34}$

Namun, berdasarkan diagram diatas ternyata tidak banyak produsen yang melakukan sertifikasi halal dibandingkan bertambahnya produk baru per tahunnya.Alasan klasik yang disampaikan para produsen rata-rata biaya yang mahal dan birokrasi yang rumit.Adapun jika produsen mencari lembaga selain MUI, dengan maksud mencari biaya yang lebih murah, lembaga itu

\footnotetext{
${ }^{33}$ Statsitik Sertifikasi Halal Indonesia, data diupdate per tanggal 11 Oktober 2017.

${ }^{34}$ Statsitik Sertifikasi Halal Indonesia, data diupdate per tanggal 11 Oktober 2017.
} 
hampir tidak ada. ${ }^{35}$ Sulitnya celah masuk bagi lembaga lain untuk melakukan sertifikasi halal semisal MUI, lama-kelamaan membentuk mindset masyarakat bahwa lembaga halal yang paling layak adalah LPPOM MUI. Keyakinan masyarakat telah terbangun sejak seringnya MUI memberikan layanan sertifikasi halal kepada masyarakat. Sebagai garansinya, konsumen akan terjamin produknya dan terhindar dari bahan yang mengandung unsur syubhat. Di sisi lain produsen dijanjikan akan meningkat omzet penjualannya karena mendapatkan kepercayaan yang lebih baik dari konsumen.

Relevan dengan penjelasan diatas, dalam Reasoned Action Theory Martin Fishbein dan Icek Ajzen menyatakan bahwa keputusan seseorang dapat diketahui berdasarkan kepercayaan atas hasil dari perilaku yang dilakukannya dan persepsi individu atas pandangan orang-orang terdekat terhadap perilakunya. Dengan kata lain bahwa keputusan konsumsi seseorang pada produk halal selalu didasari at as faktor kepercayaan individu terkait halal dan haramnya suatu produk. Kemudian sikap yang muncul pada individu didiasarkan atas kepercayaannya yang terhubung dengan pandangan orang lain at as perilaku tersebut. Maka program sertifikasi halal yang dikampanyekan oleh MUI dalam konteks ini dapat dianggap sebagai dorongan sosial untuk menentukan sikap produsen serta preferensi konsumen. ${ }^{36}$

Garansi MUI kepada konsumen pada akhirnya dapat dilihat pada Laporan dari Global Islamic Economy 2014, yang merilis negara-negara dengan konsumsi makanan halal terbesar di dunia, dimana peringkat pertama adalah Indonesia, dengan nilai pasar mencapai US\$ 190,4 miliar atau sekitar Rp 2.590 triliyun, yang kemudian disusul Turki dengan US\$168,5 miliar, Paki-

${ }^{35}$ Ketidakmampuan lembaga lain untuk melakukan sertifikasi 'halal disebabkan oleh standar regulasi yang tidak memihak secara politis dan tingginya perlawanan MUI terhadap institusi yang akan melaksanakan sertifikasi halal. Seperti dalam kasus perumusan Undang-Undang Jaminan Produk Halal tahun 2014 di mana Undang-undang tersebut menetapkan bahwa kewenangan sertifikasi halal adalah Badan Pelaksana Pengamanan Produk Halal (BPJPH) Departemen Agama Republik Indonesia. Perumusan UU tersebut secara spontan mendapat kritik dan penolakan dari LPPOM MUI. MUI menolak keras hal itu karena akan "mengancam" keberadaannya. Alasan diplomatik MUI bahwa UU tersebut bertentangan dengan peraturan yang sudah ada sebelumnya.

${ }^{36}$ Martin Fishbein, Icek Ajzen, Predicting and Changing Behavior: The Reasoned Action Approach, Routledge: Psicology Press, 2015 
stan US\$ 108,4 Miliar, dan Iran dengan US\$ 97 miliar.Sampai pada tahun 2017 ini, Indonesia masih tetap mendominasi peringkat pertama Top Muslim Consumer Food Expenditure Market ${ }^{37}$ dengan nilai pasar mencapai US\$154,9 Miliar, yang disusul oleh Turkey US\$ 115,5 Miliar, Pakistan US\$ 106 Miliar, Mesir US\$ 77,5 Miliar, dan Bangladesh US\$ 68,5 Miliar. ${ }^{38}$

Dari deskripsi diatas, dapat dilihat bagaimana proses kuasa hegemoni berlangsung. Penegasan Bourdieu tentang sistem simbolik berperan sebagai instrumen dominasi memberikan ciri khas tersendiri bagi orientasi teoritiknya.Mereka yang didomonasi berada pada posisi subordinat yang tidak dipersenjatai dengan habitus, dan tidak memungkinkan menciptakan kode simbol sendiri.Dan mereka yang didominasi menerima secara sukarela pembedaan jenjang sosial yang diproduksi oleh kelompok dominan.Pemahaman tentang Instrumen dominasi ini berada dalam satu semangat pada diskursus pemikiran Foucault tentang kuasa hegemonik yang menjelaskan bahwa kuasa tidak semata-mata berasal dari atas (top-down), tetapi kesepakatan itu lebih banyak berasal dari bawah karena kuasa bisa melintasi bermacam institusi sosial di mana potensi-potensi oposisi bisa diredefinisi dan dipersekutukan kembali ke dalam relasi kuasa sehingga membentuk dominasi yang bersifat hegemonik.

Setidaknya, ada beberapa hal mendasar dari berlangsungnya moda kuasa hegemonik melalui budaya dalam kasus-kasus di atas: pertama, signifikansi ranah sosial-kultural, dimana kuasa dibangun, diwacanakan, dan dipraktikkan melalui interaksi sosial dengan dukungan wacana dan praktik kultural dalam sebuah masyarakat yang dan kedua signifikansi formasi sosio-kultural, dimana kuasa dijalankan terus-menerus melalui institusionalisasi simbol dan modal yang dimiliki sebuah kelas secara terus-menerus; ketiga, terciptanya subjeksubjek sosial yang mengikuti ideologi kultural dalam formasi diskursif sehingga kuasa dari kelas pengarah tidak terbaca sebagai kepentingan

${ }^{37}$ Indikator yang diggunakan diantaranya krtiteria bahan produk halal, dan merek produk

${ }^{38}$ State of The Global Islamic Economy 2016-2017 Report, Developed and Produced by Thomson Routers, p28 
tetapi kewajaran; dan, keempat kepandaian kelas pengarah dalam mewacanakan kepentingannya dengan melampaui dan melintasi bermacam kelas dan golongan sosial sehingga eksnominasi ideologi budayanya mampu menciptakan konsensus terus-menerus terhadap kuasanya.

Kemudian mengapa keadaan ini berbeda dengan perilaku produsen terhadap produk halal.Dimana kesadaran produsen relatif stagnan.Data statistik LPPOM MUI di atas secara jelas menggambarkan ketimpangan pertumbuhan produk dengan produk yang tersertifikasi halal.Artinya bahwa kuasa simbolik hanya bekerja pada ranah kelompok konsumen yang mengkonsumsi produk halal namun tidak bekerja pada kelompok produsen yang memproduksi produk halal.Beberapa hal yang menyebabkan rendahnya kesadaran produsen dalam memproduksi produk halal adalah adanya faktor ekonomi, faktor yuridis, dan faktor kepercayaan. ${ }^{39}$ Dalam perspektif produsen, faktor ekonomi menjadi penting untuk dipertimbangkan sebagai bagian dari keputusan penjualan dan laba.Termasuk biaya sertifikasi halal yang relatif tinggi, dengan jangka waktu yang pendek serta birokrasi yang panjang sangat mempengaruhi keputusan produsen untuk mensertifikasikan produknya. Biaya tinggi dalam sertifikasi halal sangat mempengaruhi harga akhir penjualan.Sedangkan konsumen belum tentu membeli produknya karena ragamnya faktor selera, merek, dan budaya konsumen.

\footnotetext{
${ }^{39}$ Disamping faktor primer diatas, ada faktor sekunder yaitu aspek komitmen keagamaan, permintaan konsumen, dan fasilitas pemerintah. Dari survei yang dilakukan oleh P2E LIPI pada tahun 2011 dijelaskan bahwa dari 100 responden yang diambil secara acak menemukan tiga klasifikasi produsen. Produser yang memiliki komitmen religius tinggi berjumlah 49,3\% dari seluruh responden. Produk telah disertifikasi untuk 30,77\% produk, sementara sisanya 69,23\% tidak atau belum memiliki sertifikat halal. Produsen dengan komitmen agama menengah yang sudah memiliki persentase sertifikasi halal hampir sama dengan mereka yang memiliki komitmen tinggi $31,71 \%$, sedangkan yang tidak ditentukan sebanyak $68,29 \%$. dan mereka yang sudah memiliki sertifikat halal menerima sebagian besar fasilitas dari pemerintah daerah. Sementara di kelompok produsen dengan komitmen religius rendah, produk bersertifikat dengan produk non-certified sama, 50\%. maka sebenarnya persentase antara masing-masing kelompok responden tidak signifikan. Akuisisi lebih banyak sertifikat didorong oleh fasilitas subsidi dari pemerintah daerah. Meski ada produsen yang bekerja sendiri, tapi jumlahnya kecil. Iwan Zainul Fuad, "Kesadaran Hukum Pengusaha Kecil di Bidang Pangan dalam Kemasan di Kota Semarang terhadap Regulasi Sertifikasi produk Halal", Tesis, Universitas Diponegoro, 09 April 2010,
} 
Kemudian bagi produsen, adanya sertifikasi halal akan merubah seluruh proses bisnis, seperti halnya peralatan produksi harus disesuaikan agar memenuhi standar halal. Di samping itu, produsen juga harus memiliki karyawan yang kompeten untuk mengawasi proses produksi supaya memnuhi standar halal. Bahkan untuk produk makanan, proses sertifikasi sangat kompleks dan tidak mudah untuk dilakukan mengingat jumlah bahan baku yang dibutuhkan dalam proses produksi sangat beragam hingga diperkirakan membutuhkan 15 jenis bahan baku. Maka proses perubahan cara-cara produksi hingga alat-alat produksi yang digunakan tersebut masih sulit dilakukan produsen karena faktor biaya transformasi alat dan proses produksi yang mahal. ${ }^{40}$

Dari aspek yuridis, at uran hukum yang tumpang tindih dan bersifat longgar, mengakibatkan produsen tidak memiliki efek jera atas sanksi hukum jika tidak melakukan sertifikasi halal. Karena selama ini, ketika banyak pemberitaan media terkait pelanggaran-pelanggaran yang dilakukan perusahaan atas produk yang sebelumnya dinyatakan halal namun kemudian teridentifikasi ada kandungan bahan haram (minyak babi misalnya), maka MUI hanya bisa memperingatkan perusahaan itu untuk segera memeriksakan kembali produknya pada LPPOM MUI. Dan tidak ada tindakan tegas lain yang melebihi peringatan itu.

Dan ketiga, adanya faktor kepercayaan produsen terhadap kualitas sertifikasi halal MUI, khususnya MUI di tingkat provinsi. Faktor itu muncul karena proses pelaksanaan sertifikasi halal provinsi terkesan tidak ketat. Apalagi dengan seringnya muncul fakta bahwa produk yang tersertifikasi halal masih mengandung bahan yang diharamkan oleh BPOM banyak terjadi di daerah-daerah.Maka berdasarkan fakta itu, sebagian produsen meyakini bahwa sertifikasi halal di tingkat provinsi hanya bermotif bisnis dan komodifikasi sertifikat halal saja.

Sekali lagi, moda kuasa tersebut bisa menjadi kekuatan positif ketika dibangun diatas interaksi dan komunikasi kultural yang saling terbuka dan menguntungkan. Artinya selalu ada kritik yang kon-

${ }^{40}$ Endang Tjitjroresmi dan Diah Setiri Suhodo, Peluang Usaha Produk Halal di Pasar Global: Perilaku Produsen dalam memproduksi produk Halal(Jakarta: LIPI Press, 2015), 2. 
struktif dari kelas subordinat untuk mendinamisasi keberlangsungan sosial.Tetapi, ketika kelas subordinat tidak pernah mendapatkan kesempatan untuk berbicara di ruang publik dan hanya menjadi subjek-subjek yang pasif melalui wacana dan praktik kultural, maka kondisi ini bisa menjadi politik budaya yang berbahaya. Kondisi ini akan menimbulkan moda kuasa hegemoni dalam sebuah masyarakat yang berjalan dengan teratur dan wajar karena mampu memadukan moda ekonomi dan kultural sebagai praksis kekuasaan yang bersifat eksploitatif dan didukung dengan ketertundukan kelas-kelas subordinat sebagai subjek-subjek diskursif yang tidak bisa berbuat apa-apa.

Foucault secara konseptual memaparkan bahwa di mana ada kuasa, maka di situlah akan muncul resistensi. Resistensi sendiri mempunyai beberapa karakteristik.Pertama, bahwa resistensi pada dasarnya selalu muncul ketika berlangsung sebuah kuasa.Kedua, sama dengan beroperasinya kuasa yang menggunakan beragam poin, resistensi juga bisa berasal dari beragam poin. Ketiga, resistensi bersifat plural.Pluralitas ini bisa menjadi keunggulan karena bisa mewujudkan resistensi tidak dalam kesatuan yang mudah dideteksi, tetapi juga bisa merugikan ketika tidak bisa diorganisir dan diolah kembali.

Ketiga, resistensi hanya bisa berjalan efektif atau menghasilkan perubahan ketika ia berlangsung dalam lingkup strategis relasi kuasa. Artinya, untuk melawan kuasa, subjek-subjek yang sadar dan kritis tidak harus sepenuhnya membuat poin maupun terma baru yang bertentangan dengan relasi kuasa, tetapi dengan memaknai kembali relasi yang ada dan kemudian digunakan untuk memetakan kemungkinan-kemungkinan yang bisa digunakan menyerang balik. Keempat, dalam resistensi dibutuhkan poin resistensi yang bersifat mobile dan cepat berubah sehingga bisa memecah relasi yang sudah mapan dalam masyarakat untuk kemudian dilakukan reorganisasi dan re-grouping terhadap mereka-mereka yang punya kesadaran kritis, sehingga mampu memunculkan wacana dan pengetahuan baru yang bisa memberikan penyadaran dan melampaui stratifikasi sosial yang ada. Kelima, perlu dilakukan kodifikasi atau semacam pengaturan yang bersifat strategis terhadap poin-poin resistensi yang bersifat 
plural sehingga revolusi menjadi mungkin terjadi. Memang pikiran Foucault mengenai resistensi bersifat sangat ideal, dan mungkin akan sulit diwujudkan dalam masyarakat yang sudah semakin kompleks dewasa ini. Namun, pikiran-pikiran ideal itu bukan tidak mungkin diwujudkan ketika kesadaran kritis dan resistensi bisa disebarkan terus-menerus, baik dalam pola maupun strategi yang beragam dan terorganisir. $^{41}$

\section{PENUTUP}

Sebagai kesimpulan, ada tiga tahapan penting yang dilakukan oleh MUI dalam berkontestasi untuk menciptakan kuasa simbolik atas fatwa sertifikasi halal di Indonesia..Pertama, Fatwa sertifikasi halal dipakai untuk menguatkan bangunan struktur dominasi bagi perangkat pemerintahan.Kedua, fatwa sertifikasi halal kemudian digunakan untuk melegitimasikan diri dalam struktur sosial melalui peran pemerintah.Dan ketiga fatwa sertifikasi halal sebagai sarana dominasi simbolik untuk melegitimasi mindset masyarakat dalam kaitannya produk pangan yang baik dan halal.

\section{DAFTAR RUJUKAN}

Abdullah, et.al, dalam Mahdi Barzooei and Maryam Asgari.“The Evolution of Halal from a Religious Symbol to a Brand", Czech Journal of Social Sciences, Business and Economics, Vol. 3, Issue 1, 2014.

Afroniati, Lies. "Analisis Ekonomi Politik Sertifikasi Halal oleh Majlis Ulama Indonesia", Jurnal Kebijakan dan Administrasi Publik, Vol 18, No. 1-Mei 2014.

Bourdieu,Pierre.The Social Space and The Genesis of Groups. Transleted by Richard Nice Jurnal Theorie et methodes, Social Science Information. SAGE, London, Beverly Hills and New Delhi, 1989.

${ }^{41}$ Michel Foucault, The Will to Knowledge, The History of Sexualities Volume 1, English trans. Robert Hurley (London: Penguin Books.1998). 
"Social Space and Symbolic Power",Sociological Theory, Vol. 7, No. 1, Spring, 1989.

-----------Language and Symbolic Power, Malden; Polity Press, 1991.

Barthes, Roland.Mytologies, The Noonday Press; Farrar, Straus \& Giroux, 1972.

Burlin, Paisol. “Reformulasi Yuridis Pengaturan Produk Pangan Halal bagi Konsumen Muslim di Indonesia",Ahkam: Vol. XIV, No. 1, Januari 2014.

Foucault, Michel.Power Knowledge. Brighton: Harvester. 2002.

Fashri, Fauzi.Pierre Bourdieu, Menyingkap Kuasa Simbol. Yogyakarta: Jalasutra, 2014.

Faidah, Mutimmatul.“Sertifikasi Halal di Indonesia dari Civil Society menuju Relasi Kuasa antara Negara dan Agama", Islamica, Volume 11, Nomor 2, Maret 2017.

Fishbein, Martin, Ajzen, Icek.Predicting and Changing Behavior: The Reasoned Action Approach.Routledge: Psicology Press, 2015

Fuad, Iwan Zainul.“Kesadaran Hukum Pengusaha Kecil di Bidang Pangan dalam Kemasan di Kota Semarang terhadap Regulasi Sertifikasi produk Halal," Tesis, Universitas Diponegoro, 09 April 2010.

Foucault, Michel. The Will to Knowledge, The History of Sexualities Volume 1 (English trans. Robert Hurley). London: Penguin Books.1998.

Hallet, Tim. "Symbolic Power and Organization Culture", Sociological Theory, Vol. 21, No. 2 (Jun., 2003),

Hasan, KN. Sofyan. “Formulasi Hukum dan Pentingnya JaminanKepastian Hukum Produk Pangan Halaldalam Hukum Nasional".NURANI, Vol. 15, No. 2, Desember 2015.

Hasan, KN. Sofyan. "Kepastian Hukum Sertifikasi dan Labelisasi Halal Produk Pangan" Jurnal Dinamika Hukum, Vol. 14 No. 2 Mei 2014. 
John Mac, Dougall, Ketua MUI KH.Hasan Basri: “Kalau Umat Islam Tenteram,NegaraIniTenteram”, 20 Juli 2010.

Jusmaliani.Komitmen Beragama Produsen dan Perilaku terhadap Jaminan Produk Halal, dalam ndang Tjitjroresmi dan Diah Setiri Suhodo, Peluang Usaha Produk Halal di Pasar Global: Perilaku Produsen dalam memproduksi produk Halal.Jakarta: LIPI Press, 2015.

Kemenag dan MUI berebut Stempel Halal, http:///www.jpnn.com, 04 Maret 2014.

Melchert, Christoper, The Formation of Te Sunni School of Law 9TH-10TH Centuries C.E. Leiden: Brill. 1997.

Konoras, Abdurrahman.Jaminan Produk Halal di Indonesia, Perspektif Hukum Perlindungan Konsumen.Jakarta; Rajawali Press, 2017.

Lévi-Strauss, Claude. Antropologi Struktural (terj. Ninik RS). Yogyakarta: Kreasi Wacana, 2005.

Mukafi. NU Online: Konsumen Puas Pelayanan Sertifikasi Halal NU, http://www.nu.or.id.,Senin 14 April2014, 22:06

Mudzhar, Muhammad Atho. Fatwa Fatwa Majelis Ulama Indonesia; Sebuah StudiTentang Pemikiran Hukum Islam di Indonesia 1975-1988.Jakarta: INIS, 1993.

Mahfud MD, Moh.Membangun Politik Hukum,Menegakkan Kosntitusi. Rajawali Pers, Jakarta, 2010.

Mashudi.Konstruksi Hukum dan Respon Masyarakat terhadap Sertifikasi Produk Halal.Yogyakarta: Pustaka Pelajar, 2015.

Rahardjo, Satjipto.Membedah Hukum Progresif. Jakarta:KOMPAS, 2006.

Statsitik Sertifikasi Halal Indonesia, data diupdate per tanggal 11 Oktober 2017.

State of The Global Islamic Economy 2016-2017 Report, Developed and Produced by Thomson Routers

Tjitjroresmi, Endang, Diah Setiri Suhodo. Peluang Usaha Produk Halal di Pasar Global: Perilaku Produsen dalam memproduksi produk Halal, Jakarta: LIPI Press, 2015. 
Suad Fikriawan

Undang-undang Nomor 33 Tahun 2014 tentang Jaminan Produk Halal. Wacquant, Loïc. On Symbolic Power and Group-Making: Pierre Bourdieu's Reframing of Class. (Oslo, Forlaget Manifest), November 2007. 